\title{
Investigating the Liquid Moisture Transport Behavior of Cotton and Polyester Cotton Blended Woven Fabric
}

\author{
Salma Farooq $^{1 \mathrm{a}}$, Saira Faisal ${ }^{\text {1b }}$, Fareha Asim ${ }^{1 \mathrm{c}}$ \\ RECEIVED ON 25.09.2019, ACCEPTED ON 16.12.2020
}

\begin{abstract}
This study focused on the effects of varying the warp and weft densities and blend ratio on the overall liquid transport behavior of plain woven $100 \%$ cotton and polyester/cotton blended fabric. Overall Moisture Management Capability (OMMC) and Accumulative One-way Transport Index (AOTI) along with wetting and spreading time of the top and bottom surfaces was measured on moisture management tester. The results were used as a basis to grade the fabric for its moisture transport behavior. It was observed that polyester/cotton blends have an overall higher accumulative one-way transport index and overall moisture management capability than $100 \%$ cotton fabric. Furthermore, an increase in the polyester content in the fabric resulted in a significant increase in the transport of moisture. However less number of warp and weft yarns in the blended fabric improved the overall moisture management capability of the fabric.
\end{abstract}

Keywords: Liquid Moisture Transport Behavior, Accumulative One-way Transport Index, Blend Ratio, Overall Moisture Management Capability, Warp Density and Weft Density.

\section{INTRODUCTION}

$\mathrm{T}$ The thermo-physiological comfort level of apparel can be determined by its ability to transport perspiration from the layer next to the skin to the outer layer and subsequently to the environment. In hot and humid climate, perspiration affects wearer comfort. Wearer will feel more comfortable when this is quickly transported away from the skin in the form of a liquid or vapour. This is because the fabric touching the skin will feel dry. An effective moisture management system includes complete transfer of moisture vapour and liquid from the skin to the environment [1]. The moisture management properties of a fabric are influenced by numerous factors such as the nature of fibre (hydrophilic or hydrophobic), blend ratio and yarn and fabric constructional parameters etc.
Yarn constructional parameters have a substantial effect on the moisture management properties of woven as well as knitted fabrics [2]. Finer counts yield higher absorption rate and high wetted radius with reduced wetting time. However, higher twist coefficient results in reduced absorption rate and wetted radius. Das et al. [3] claimed that blend ratio, yarn count and twist are the significant factors for vapour and liquid moisture transmission in a polyester/viscose blended fabric. Finer count, low yarn twist level and an increase in polyester proportion of a polyester/viscose blended woven fabric resulted in decreased air and water permeability [3].

Namligöz et al. [4] compared the moisture transmission indices of pure cotton, polyester and polyester/cotton blends and concluded that a fabric made of $100 \%$ cotton and $100 \%$ polyester is not suitable for efficient transport and wetting of a liquid.

${ }^{1}$ Department of Textile Engineering, NED University of Engineering \& Technology, Karachi, Pakistan.

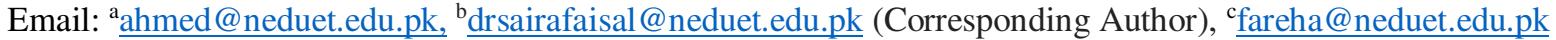

This is an open access article published by Mehran University of Engineering and Technology, Jamshoro under CC BY 4.0 International License. 
However polyester/cotton blended fabrics were found to possess acceptable liquid absorption and conveyance. Effect of polyester filament linear density on liquid moisture management property, air permeability and thermal conductivity was described as major factor for the comfort level of the fabric as claimed by Kaynak and Babaarslan [5]. The researchers pointed out that coarser polyester filament knitted fabric had rapid liquid transfer. Microfilament polyester knitted fabric has less air permeability than regular filament polyester. In one related study, it was found that vapour permeability is not dependent upon the linear density of polyester filaments. However, the thermal properties can be affected with the change in linear density. It was also reported that air permeability and wettability both decreases with an increase in fibre diameter but wickability of a fabric improved with finer count of the yarn [6]. In one study related to the effect of yarn linear density on the water absorbency of a double layer knitted fabric, it was concluded that a coarser polypropylene yarn with finer cotton yarn double layer fabric has better permeability [7].

Kara and Akgun [8] assessed the effects of the weft yarns having different fiber contents (different blended ratios of fibers such as cotton, coolmax, cordura, thermocool and elastane) and the effects of certain fabric constructional parameters on moisture management properties of commercially used denim fabrics. It was observed that the AOTI and OMMC values of denim fabrics also increased when the cotton ratio in weft yarn was increased. It was also reported that the fabric parameters which have a marked influence on the moisture management properties of fabrics are the fabric thickness, fabric weight, fabric bulk density and also crimp and floating length of yarns in the weave structure [8]. The effect of increasing bamboo content on the moisture management capability of a bamboo/cotton knitted fabric was investigated by Chidambaram Prakasha et al. and concluded that increase in bamboo content decreases the overall OMMC values of the fabric [9]. It has also been observed that when different weft yarns (mainly regenerated) but same warp yarn was used in a woven fabric bamboo and promodal have almost similar behavior as far as air permeability, wetting, and wicking and water vapour permeability of woven fabric is concerned. A slightly better effect was observed with tencel and modal but these fibres are relatively expensive [9].

Baltušnikaite et al. [10] reported that the transmission of moisture is greatly affected by the fabric structure and fibre surface energy. It was claimed that plain knitted fabric has lower moisture transport capability than fleecy fabrics, and the fabrics with higher surface energy can effectively manage the moisture in comparison to the fabrics with lower surface energy. Also, tightness factor has to be taken into consideration as increase in covering factor improves the moisture management properties. In one study, the effect of texturizing on the wicking and drying rate of $100 \%$ polyester woven fabric was investigated and it was found that the non-texturized yarn dried faster but the texturized polyester possessed better wicking capability [11].

In the light of the review of related work presented above, this work aimed to investigate the effects of warp density and weft density on moisture transmission of $100 \%$ cotton and in a polyester/cotton blended fabric. The effect of the variation in warp per inch and weft per inch was evaluated in terms of wettability, transfer rate and Moisture management index. This research will help to develop an appropriate woven fabric especially for shirting during hot and humid climate.

\section{EXPERIMENTAL SETUP}

\subsection{Materials and Methods}

Nine samples of woven fabric having 40s English cotton count and three different warp and weft densities $(90 \times 50,100 \times 65$ and $110 \times 70)$ were developed and used in this study. Out of these nine samples, three samples were of $100 \%$ cotton and six were of the polyester/cotton blended woven fabrics with different blend ratios (65:35 and 80:20). Detailed specifications of the samples are provided in Table 1. All the fabric samples were prepared on SL 8900 Evergreen loom, which is a single rod, single rapier weft insertion loom with dobby controlled shedding system. 


\begin{tabular}{|c|c|c|c|}
\hline \multicolumn{4}{|c|}{$\begin{array}{c}\text { Table 1: Technical Specifications of the } \\
\text { Developed Samples }\end{array}$} \\
\hline $\begin{array}{l}\text { Sample } \\
\text { No. }\end{array}$ & Fiber Type & $\begin{array}{l}\text { Polyester } \\
(\%)\end{array}$ & $\begin{array}{l}\text { Cotton } \\
(\%)\end{array}$ \\
\hline 1 & Cotton & 0 & 100 \\
\hline 2 & Polyester/Cotton & 65 & 35 \\
\hline 3 & Polyester/Cotton & 80 & 20 \\
\hline 4 & Cotton & 0 & 100 \\
\hline 5 & Polyester/Cotton & 65 & 35 \\
\hline 6 & Polyester/Cotton & 80 & 20 \\
\hline 7 & Cotton & 0 & 100 \\
\hline 8 & Polyester/Cotton & 65 & 35 \\
\hline 9 & Polyester/Cotton & 80 & 20 \\
\hline
\end{tabular}

\begin{tabular}{|c|c|c|c|}
\hline \multicolumn{4}{|c|}{$\begin{array}{c}\text { Table 2: Recipes used for Desizing, Scouring and } \\
\text { Bleaching of Developed Samples }\end{array}$} \\
\hline No. & $\begin{array}{l}\text { Reagent } \\
\text { Name }\end{array}$ & $\begin{array}{l}\text { Generic } \\
\text { Name }\end{array}$ & $\begin{array}{l}\text { Quantity } \\
(\mathrm{g} / \mathrm{l})\end{array}$ \\
\hline \multicolumn{4}{|c|}{ Desizing } \\
\hline 1 & Levotan RGA & $\begin{array}{c}\text { Wetting } \\
\text { agent }\end{array}$ & 3 \\
\hline 2 & Bexion NE & $\begin{array}{c}\text { Sequestering } \\
\text { agent }\end{array}$ & 4 \\
\hline 3 & Optisize cool & Enzyme & 0.1 \\
\hline \multicolumn{4}{|c|}{ Scouring } \\
\hline 1 & Levotan RGA & $\begin{array}{c}\text { Wetting } \\
\text { agent }\end{array}$ & 2 \\
\hline 2 & Inverter ED & $\begin{array}{l}\text { Sequestering } \\
\text { agent }\end{array}$ & 1 \\
\hline 3 & $\begin{array}{c}\text { Sodium } \\
\text { hydroxide }\end{array}$ & Caustic & 15 \\
\hline \multicolumn{4}{|c|}{ Bleaching } \\
\hline 1 & Levotan RGA & $\begin{array}{l}\text { Wetting } \\
\text { agent }\end{array}$ & 2 \\
\hline 2 & DSP & Stabilizer & 8 \\
\hline 3 & Inverter ED & $\begin{array}{l}\text { Sequestering } \\
\text { agent }\end{array}$ & 1 \\
\hline 4 & $\begin{array}{c}\text { Sodium } \\
\text { hydroxide }\end{array}$ & Caustic & 15 \\
\hline 5 & $\begin{array}{l}\text { Hydrogen } \\
\text { peroxide }\end{array}$ & & 35 \\
\hline
\end{tabular}

The samples were desized, scoured and bleached in the laboratory using exhaust techniques as per recipes given in Table 2. Fabrics that are coated with a layer (size or finish) and have impurities are not recommended for fabric thickness and moisture management testing as presence of these impurities have adverse effect upon the fabric absorbency and appearance.

Desizing was done at $90^{\circ} \mathrm{C}$ for 45 minutes which was followed by hot and cold wash. Scouring was done at $95^{\circ} \mathrm{C}$ for $40-45$ minutes which was followed by hot and cold wash respectively. The desized and scoured fabrics were then bleached using $\mathrm{H}_{2} \mathrm{O}_{2}$ as a bleaching agent. Bleaching was performed for 35 minutes at $95^{\circ} \mathrm{C}$ using Ahiba HT dyeing machine. After the completion of the bleaching process fabric was hot washed followed by cold wash and finally dried.

\subsection{Fabric Physical Properties}

Physical properties of these developed fabrics such as yarn count (English system, Ne), thickness and mass per unit area (area density) were determined according to ASTM D1907/D1907M-12 [12], ASTM D1777-96 [13], and ASTM D3776 / D3776M-09a [14], respectively. Fabric density and porosity of a fabric were calculated using equation (1) and (2), respectively, and the results are provided in Table 3. The samples were conditioned at $20^{\circ} \mathrm{C}$ and $65 \%$ relative humidity for 24 hours prior carrying out any measurement.

Fabric Density $=\frac{\text { Area Density }\left(g / m^{2}\right)}{\text { Thickness }(\mathrm{m})}$

Porosity $=1-\left(\frac{\text { Fabric Density }}{\text { Fiber Density }}\right)$

\subsection{Moisture Management Testing}

SDL ATLAS MMT tester was used to measure the moisture management properties of the nine samples according to AATCC 195-2011 test method [15]. This tester measures electrical resistance by direct contact which is then used to calculate the wetting time, spreading rate, transport of moisture from bottom to top layer and moisture management capability [15].

\section{RESULTS AND DISCUSSION}

The results for the moisture transport properties including Wetting Time $\left(\mathrm{WT}_{\mathrm{t}}\right.$ and $\mathrm{WT}_{\mathrm{b}}$ ), Spreading Speed $\left(\mathrm{SS}_{\mathrm{t}}\right.$ and $\left.\mathrm{SS}_{\mathrm{b}}\right)$, Absorption Rate $\left(\mathrm{AR}_{\mathrm{t}}\right.$ and $\left.\mathrm{AR}_{\mathrm{b}}\right)$, Accumulative One-way Transport Index (AOTI) and Overall Moisture Management Capacity (OMMC) of each of the samples are presented in Table 4. In order to evaluate the effects of blend ratio and density $\left(\mathrm{w}_{\mathrm{p}}\right.$, $\mathrm{w}_{\mathrm{f}}$ ) on the AOTI and OMMC value of the fabrics Analysis of Variance (ANOVA) test (two-way) was also performed. The results are shown in Table 5. 
Investigating the Liquid Moisture Transport Behavior of Cotton and Polyester Cotton Blended Woven Fabric

\begin{tabular}{|c|c|c|c|c|c|c|c|c|c|c|}
\hline \multicolumn{10}{|c|}{ Table 3: Physical Properties of the Developed Samples } \\
\hline $\begin{array}{c}\text { Sample } \\
\text { No. }\end{array}$ & $\begin{array}{c}\text { Density } \\
\left(\mathrm{W}_{\mathrm{p}},\right. \\
\left.\mathrm{W}_{\mathrm{f}}\right)\end{array}$ & $\begin{array}{c}\text { Blend } \\
\text { Ratio } \\
(\mathrm{PC})\end{array}$ & $\begin{array}{c}\text { Thickness } \\
(\mathrm{mm})\end{array}$ & $\begin{array}{c}\text { Count } \\
\left(\mathrm{W}_{\mathrm{p}},\right. \\
\left.\mathrm{W}_{\mathrm{f}}\right)\end{array}$ & $\begin{array}{c}\text { Ends } \\
\text { per } \\
\text { inch }\end{array}$ & $\begin{array}{c}\text { Picks } \\
\text { per } \\
\text { inch }\end{array}$ & $\begin{array}{c}\text { Area } \\
\text { Density } \\
\left(\mathrm{g} / \mathrm{m}^{2}\right)\end{array}$ & $\begin{array}{c}\text { Fibre } \\
\text { Density } \\
\left(\mathrm{g} / \mathrm{m}^{2}\right)\end{array}$ & $\begin{array}{c}\text { Fabric } \\
\text { Density } \\
\left(\mathrm{g} / \mathrm{m}^{2}\right)\end{array}$ & $\begin{array}{c}\text { Porosity } \\
(\%)\end{array}$ \\
\hline 1 & $90 \times 50$ & $0: 100$ & 0.32 & 40 & 90 & 50 & 89 & 1540000 & 276719 & 82 \\
\hline 2 & $90 \times 50$ & $65: 35$ & 0.25 & 40 & 90 & 50 & 89 & 1390500 & 354200 & 75 \\
\hline 3 & $90 \times 50$ & $80: 20$ & 0.25 & 40 & 90 & 50 & 89 & 1356000 & 354200 & 74 \\
\hline 4 & $100 \times 65$ & $0: 100$ & 0.28 & 40 & 100 & 65 & 102 & 1540000 & 367703 & 76 \\
\hline 5 & $100 \times 65$ & $65: 35$ & 0.28 & 40 & 100 & 65 & 104 & 1390500 & 372723 & 73 \\
\hline 6 & $100 \times 65$ & $80: 20$ & 0.26 & 40 & 100 & 65 & 104 & 1356000 & 401394 & 70 \\
\hline 7 & $110 \times 70$ & $0: 100$ & 0.28 & 40 & 110 & 70 & 114 & 1540000 & 406607 & 74 \\
\hline 8 & $110 \times 70$ & $65: 35$ & 0.28 & 40 & 110 & 70 & 114 & 1390500 & 406607 & 71 \\
\hline 9 & $110 \times 70$ & $80: 20$ & 0.27 & 40 & 110 & 70 & 114 & 1356000 & 421667 & 69 \\
\hline
\end{tabular}

\begin{tabular}{|c|c|c|c|c|c|c|c|c|c|c|}
\hline \multicolumn{10}{|c|}{ Table 4: Moisture Transport Properties of Developed Samples } \\
\hline $\begin{array}{c}\text { S. } \\
\#\end{array}$ & $\begin{array}{c}\text { Density } \\
\left(\mathrm{W}_{\mathrm{p}}, \mathrm{W}_{\mathrm{f}}\right)\end{array}$ & $\begin{array}{c}\text { Blend } \\
\text { Ratio }(\mathrm{PC})\end{array}$ & $\begin{array}{c}\mathrm{WT}_{\mathrm{t}} \\
(\mathrm{sec})\end{array}$ & $\begin{array}{c}\mathrm{WT}_{\mathrm{b}} \\
(\mathrm{sec})\end{array}$ & $\begin{array}{c}\mathrm{AR}_{\mathrm{t}} \\
(\% / \mathrm{sec})\end{array}$ & $\begin{array}{c}\mathrm{AR}_{\mathrm{b}} \\
(\% / \mathrm{sec})\end{array}$ & $\begin{array}{c}\mathrm{SS}_{\mathrm{t}} \\
(\mathrm{mm} / \mathrm{sec})\end{array}$ & $\begin{array}{c}\mathrm{SS}_{\mathrm{b}} \\
(\mathrm{mm} / \mathrm{sec})\end{array}$ & $\begin{array}{c}\text { AOTI } \\
(\%)\end{array}$ & OMMC \\
\hline 1 & $90 \times 50$ & $0: 100$ & 2.30 & 2.33 & 50.95 & 63.75 & 7.18 & 7.14 & 115.97 & 0.584 \\
\hline 2 & $90 \times 50$ & $65: 35$ & 2.79 & 2.81 & 24.39 & 52.61 & 7.66 & 8.10 & 195.35 & 0.674 \\
\hline 3 & $90 \times 50$ & $80: 20$ & 1.98 & 2.02 & 66.21 & 76.55 & 9.16 & 9.08 & 227.43 & 0.736 \\
\hline 4 & $100 \times 65$ & $0: 100$ & 3.64 & 4.12 & 43.5 & 39.69 & 5.49 & 4.99 & 151.77 & 0.557 \\
\hline 5 & $100 \times 65$ & $65: 35$ & 2.63 & 2.64 & 37.51 & 59.84 & 6.89 & 8.16 & 202.98 & 0.689 \\
\hline 6 & $100 \times 65$ & $80: 20$ & 2.11 & 2.12 & 52.14 & 68.85 & 8.95 & 8.90 & 232.33 & 0.727 \\
\hline 7 & $110 \times 70$ & $0: 100$ & 2.43 & 2.59 & 50.47 & 62.84 & 6.74 & 6.64 & 148.25 & 0.617 \\
\hline 8 & $110 \times 70$ & $65: 35$ & 2.17 & 2.17 & 53.19 & 68.69 & 8.38 & 8.43 & 214.68 & 0.707 \\
\hline 9 & $110 \times 70$ & $80: 20$ & 2.25 & 2.42 & 35.04 & 55.93 & 8.66 & 8.55 & 239.10 & 0.698 \\
\hline
\end{tabular}

\begin{tabular}{|c|c|c|c|c|}
\hline \multicolumn{4}{|c|}{ Table 5: Two-Way Anova Analysis of AOTI And OMMC } \\
\hline \multirow{2}{*}{ Source of Variation } & \multicolumn{2}{|c|}{ AOTI } & \multicolumn{2}{c|}{ OMMC } \\
\cline { 2 - 5 } & F-value & p-value & F-value & p-value \\
\hline Blend Ratio & 91.17 & $0.000^{*}$ & 21.67 & $0.007 *$ \\
\hline Density $\left(\mathrm{W}_{\mathrm{p}}, \mathrm{W}_{\mathrm{f}}\right)$ & 4.74 & 0.088 & 0.30 & 0.758 \\
\hline \multicolumn{3}{|c|}{ *statistically significant at 95\% $^{-}$} \\
\hline
\end{tabular}

\subsection{Effect on Accumulative One-Way Transport Index (AOTI)}

It can be seen from Fig. 1 that blends have an overall higher accumulative one-way transport index (AOTI). Furthermore, a higher proportion of polyester in the blended fabrics resulted in a higher accumulative oneway transport index (\%). Higher AOTI values imply that perspiration will be transferred quickly from the layer next to skin to the outer surface thus improving the comfort to the wearer. Cotton is hydrophilic in nature and has large number of hydrogen bonding sites in its structure which are responsible for holding the moisture. Thus, in case of cotton fiber, the transfer of moisture to the environment is relatively slower. While polyester being hydrophobic is unable to hold moisture and therefore transfer it rapidly to the bottom

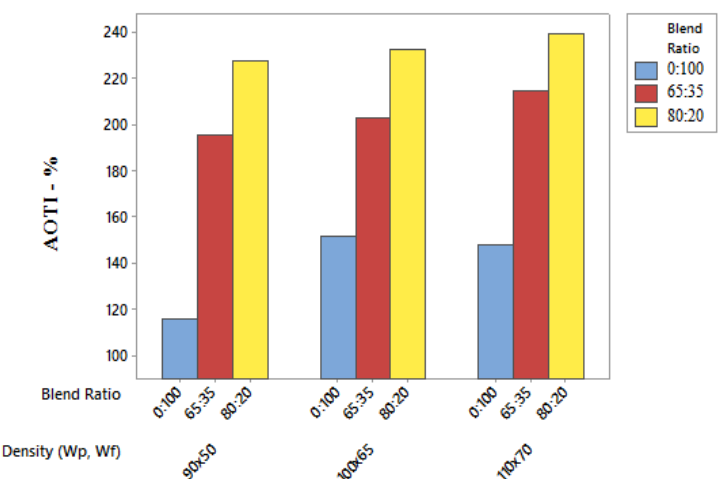

Fig. 1: AOTI Values of Developed Samples

surface $[4,16]$ which is quite apparent from the wetting time of the bottom surface $\left(\mathrm{WT}_{\mathrm{b}}\right)$ in Table 4 . Changing the warp and weft densities has a substantial effect on AOTI value, greater the number of warp and 
weft per inch of a fabric higher will be the transport index. This may be due to the lower porosity and higher capillary rise in tightly woven fabric. Moreover, it is observed from Table 5 that the effect of blend ratio on AOTI is statistically significant at $95 \%$ level.

\subsection{Effect on Overall Moisture Management Capability}

Fig. 2 shows the overall moisture management capability of prepared fabric samples which was calculated by using equation (3) keeping in consideration the transport behavior, absorbency and spreading speed of the fabric.

$\mathrm{OMMC}=\mathrm{C}_{1} \mathrm{AR}_{\mathrm{b}}+\mathrm{C}_{2} \mathrm{AOTI}+\mathrm{C}_{3} \mathrm{SS}_{\mathrm{b}}$

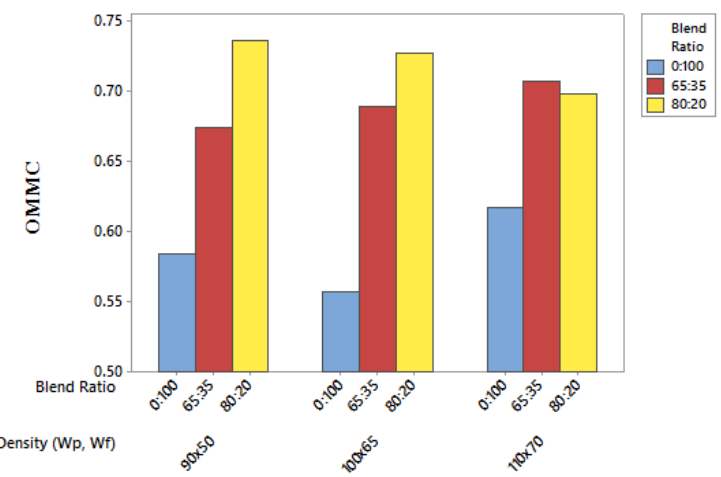

Fig. 2: Overall Moisture Management Capability (Ommc) Values of Developed Samples

In equation (3), $\mathrm{C}_{1}=0.25, \mathrm{C}_{2}=0.5$ and $\mathrm{C}_{3}=0.25$. The higher output of equation (3) will show that a fabric has excellent moisture management properties [17]. It is evident from Fig. 2 that blends have an overall higher moisture management capability. Blending ratio plays also an important role on an overall OMMC values. Higher the polyester portion higher will be the OMMC value. It is because of the fact that synthetic fibres have higher transport index and drying rate in comparison to natural fibres which have good absorption but low spreading rate. It was also observed that the variation in warp and weft densities have an impact on overall moisture management capacity of the fabric. Higher the density lower would be this capacity. This change in OMMC is basically related to quick change in $\mathrm{AOTI}$ and $\mathrm{AR}_{\mathrm{b}}$ with change in warp and weft density. Furthermore, it is observed that the effect of blend ratio on OMMC is statistically significant at $95 \%$ level. Among all the samples, the highest OMMC values were observed for the fabrics with 80:20 blend ratio. It is interesting to note than increase in warp and weft densities for blends with higher polyester content affect negatively to the OMMC behavior while for blends with higher cotton content a positive impact on OMMC have been observed.

\section{CONCLUSION}

It can be concluded that a woven fabric constructed using polyester/cotton yarns has an overall improved moisture management capability compared with an identically constructed fabric using $100 \%$ cotton yarn. For all those blends which have higher polyester content, lower warp and weft densities will favor higher OMMC values but with an increase in cotton content this will be accomplished by increasing these densities in the fabric. Though warp and weft densities do not contribute significantly to the overall moisture management behavior of the woven fabric but higher warp and weft densities favors quick transport of moisture from inner to outer surface, whether it is $100 \%$ cotton or a polyester/cotton blended fabric.

\section{ACKNOWLEDGEMENT}

The authors wish to thanks NED University of Engineering \& Technology for moral support.

\section{REFERENCES}

1. Haghi A., "Moisture Permeation of Clothing", Journal of Thermal Analysis and Calorimetry, Vol. 76, No. 3, pp. 1035-1055, 2004.

2. Özdil N., Süpüren G., Özçelik G., Průchová J., "A Study on the Moisture Transport Properties of the Cotton Knitted Fabrics in Single Jersey Structure", Tekstil ve Konfeksiyon, Vol. 19, No. 3, pp. 218-223, 2009.

3. Das B., Das A., Kothari V. K., Fangueiro R., Araújo M. D., "Studies on Moisture Transmission Properties of Pv-Blended Fabrics", The Journal of the Textile Institute, Vol. 100, No. 7, pp. 588-597, 2009.

4. Namligöz E. S., Coban S., Bahtiyari M.I., 
"Comparison of Moisture Transport Properties of the Various Woven Fabrics", Tekstil ve Konfeksiyon, Vol. 20, No. 2, pp. 93-100, 2010.

5. Kaynak H. K., Babaarslan O., "Effects of Filament Linear Density on the Comfort Related Properties of Polyester Knitted Fabrics", Fibres and Textiles in Eastern Europe, Vol. 1, No. 115, pp. 89-94, 2016.

6. Das B., Das A., Kothari V., Fanguiero R., De Araújo M., "Effect of Fibre Diameter and CrossSectional Shape on Moisture Transmission through Fabrics", Fibers and Polymers, Vol. 9, No. 2, pp. 225-231, 2008.

7. Babu B. S., Senthilkumar, P., and Senthilkumar, M., "Effect of Yarn Linear Density on Moisture Management Characteristics of Cotton/Polypropylene Double Layer Knitted Fabrics", Industria Textila, Vol. 66, No. 3, pp. 123-130, 2015.

8. Kara G., Akgun M., "Effect of Weft Yarn Fiber Contents on the Moisture Management Performance of Denim Fabrics Woven with Different Constructional Parameters", Tekstil ve Konfeksiyon, Vol. 28, No. 2, pp. 151-161, 2018.

9. Prakash C., Ramakrishnan G., Koushik C., "Effect of Blend Proportion on Moisture Management Characteristics of Bamboo/Cotton Knitted Fabrics", The Journal of the Textile Institute, Vol. 104, No. 12, pp. 1320-1326, 2013.

10. Baltušnikaite J., Abraitienė A., Stygienė L., Krauledas, S., Rubežienè V., VarnaitèŽuravliova, S., "Investigation of Moisture Transport Properties of Knitted Materials Intended for Warm Underwear", Fibres and Textiles In Eastern Europe, Vol. 4, No. 106, pp. 93-100, 2014
11. Saricam, C. and Kalaoğlu, F., "Investigation of the Wicking and Drying Behaviour of Polyester Woven Fabrics", Fibres and Textiles in Eastern Europe, Vol. 3, No. 105, pp. 73-78, 2014.

12. ASTM D1907/D1907M-12, "Standard Test Method for Linear Density of Yarn (Yarn Number) by the Skein Method", 2018.

13. ASTM D1777-96,"Standard Test Method for Thickness of Textile Materials", 2015.

14. ASTM D3776/D3776M-09a,"Standard Test Methods for Mass Per Unit Area (Weight) of Fabric", 2017.

15. AATCC Test Method 195-2011,"Liquid Moisture Management Properties of Textile Fabrics.", 2012.

16. Khan M. Z., Hussain S., Siddique H. F., Baheti V., Militky J., Azeem M., Azam A., "Improvement of Liquid Moisture Management in Plaited Knitted Fabrics", Tekstil ve Konfeksiyon, Vol. 28, No. 3, pp. 182-188, 2018.

17. Hu J., Li, Y., Yeung K.-W., Wong A. S., Xu W., "Moisture Management Tester: A Method to Characterize Fabric Liquid Moisture Management Properties", Textile Research Journal, Vol. 75, No. 1, pp. 57-62, 2005. 